\title{
ATPAPUA EROMOMIRA
}

УДК: 399.92:631.5(045)

https://doi.org/10.31470/2306-546X-2020-45-07-21

\section{СТРАТЕГІЇ ВИРОБНИЦТВА АГРАРНОЇ ПРОДУКЦІї: СВІТОВИЙ ДОСВІД}

Біла С. 0.

Актуальність теми дослідження. Подолання голоду та забезпечення населення планети Земля достатньою кількістю продовольства визнано ООН одним із стратегічних пріоритетів сталого розвитку людської цивілізації на період до 2030 року. Із зростанням кількості населення планети Земля, яке нині перевищує 7,6 млрд осіб, у XXI cm. стрімко зростає і әлобальний попит на продовольство та продукти харчування. Водночас, традиційні для XX cm. стратегії екстенсивного розвитку та «точкової» інтенсифрікації аграрного виробництва в нинішніх умовах не дають очікуваних позитивних результатів. Для світової економіки потрібні нові стратегії розвитку аграрного виробництва, здійснення "зеленої революції» з використанням здобутків IT-технологій та "Індустрії 4.0». Узагальнення світового досвіду щодо розробки та впровадження стратегій виробництва аграрної продукції у XXI cm. має вагоме теоретичне та практичне значення для всіх країн, що масово експортують аграрну продукцію, а також і для України, яка зорієнтована на лідерство у світовому аграрному виробництві. Така постановка проблеми свідчить про актуальність даної статті.

Постановка проблеми. Зростання обсягів виробництва продовольства у світовій економіці відбувається повільно і не задовольняє зростаючий попит на продукти харчування та на аграрну сировину для індустріально-промислового комплексу у світових масштабах. В таких умовах виробники товарної аграрної продукції - фермери, агро-фрірми та агрохолдінги, ТНК - змінюють та модифрікують традиційні для XX cm. стратегії аграрного виробництва. Лідуючі позиції серед нових стратегій займає перехід до високоточного землеробства та інноваційного аграрного виробництва на основі задіяння потенціалу IT-технологій. Сутність та соціально-економічні наслідки впровадження такої стратегії потребують докладного дослідження.

Аналіз останніх досліджень та публікацій. Вагомий внесок у дослідження сутності та спрямованості стратегій агарного виробництва у їх зв'язку з інноваційно-інвестиційним розвитком та з удосконаленням відносин власності здійснили українські вчені Макаренко П. М., Пілявський В. І. [1] та Шульга О. А. [2]. Іноземні вчені, такі як: К. Смаллер, У. Спеллер, Х. Мірза, Н. Бернасконі-Остервальдер, Г. Діксі та ін. [3] особливу увагу приділяли дослідженню стратегічних пріоритетів щодо мінімізації ризиків та максимізації прибутків агро-фірм та ТНК в процесі реалізації аграрних контрактів на світових ринках. Іноземні вчені Б. Кеатінг, М. Херреро, П. Карберрі [4] у своїх дослідженнях наголошували на актуальності дотримання стратеаій забезпечення продовольчої безпеки у глобальному середовищі. Натомість, залишається невисвітленим питання щодо розробки стратегій високоточного аграрного виробництва з масовим використанням інновацій та IT-технологій, дослідження соціально-економічних наслідків, що супроводжують їх впровадження у XXI cm.

Виділення недосліджених частин загальної проблеми. Проблематика дослідження сутності та складових процесу розвитку аграрного виробництва у світовому господарстві достатньо повно висвітлена у світовій економічній літературі. Натомість, для визначення стратегічних пріоритетів 
розвитку аграрного виробництва особливого значення набуває дослідження стратегій діяльності ТНК та фермерських господарств, стратегій переходу ТНК до розвитку високоточного аграрного виробництва. Невизначеними на сьогодні є тендениіі ПІІ щодо купівлі земель сільськогосподарського призначення та аналіз пріоритетів їх використання ТНК у розвинутих країнах світу та в країнах, що розвиваються. Докладного дослідження потребують i соціально-економічні наслідки масового впровадження високоточного аграрного виробництва для національної економіки країн, що мають аграрну спеціалізацію.

Постановка завдання, мети дослідження.

Мета дослідження - висвітлити сутність, визначити закономірності формування та виокремити основні очікувані соціально-економічні наслідки впровадження стратегій розвитку високоточного аграрного виробництва (на прикладі узагальнення світового досвіду діяльності аграрних ТНК).

Для досягнення мети у статmі поставлені та вирішуються наступні завдання:

- визначити основних «гравців» на світовому аграрному ринку та дослідити пріоритети їх економічної діяльності;

- дослідити сутність та складові стратегії «зеленої революції», стратегії переходу до високоточного аграрного виробництва на основі задіяння інноваційних та IT-технологій;

- визначити стратегічні цілі ТНК щодо використання придбаних земель (за рахунок прямих іноземних інвестицій) на прикладі узагальнення досвіду розвинених країн світу та країн, що розвиваються;

- визначити очікувані соціально-економічні наслідки масового впровадження стратегій високоточного аграрного виробництва ТНК та національним агробізнесом для економіки країн, що мають аграрну спеціалізацію.

Метод або методологія проведення дослідження. В процесі дослідження світового досвіду впровадження стратегій розвитку високоточного аграрного виробництва використовувалися теоретичні та емпіричні методи наукових досліджень. У статmі було використано методи історичного та логічного, аналізу та синтезу, абстрактного та конкретного, метод причиннонаслідкових зв'язків для визначення стратегічних пріоритетів спеціалізації фермерських господарств та аграрних ТНК, для визначення очікуваних соціально-економічні наслідків масового переходу до високоточного аграрного виробництва країн, що мають аграрну спеціалізацію. Синергетичний підхід, метод експертних оцінок, каузальний (причинно-наслідковий) метод наукових досліджень було задіяно для обгрунтування стратегій «зеленої революції», стратегій ТНК щодо переходу до високоточного аграрного виробництва на основі використання інноваційних та IT-технологій.

Викладення основного матеріалу (результати роботи). У сорері аграрного виробництва представлені: фрермери, домашні господарства, державний аграрний сектор, національні агрофрірми та агрохолдінги, інтернаціональні ТНК. Фермерські господарства, як правило, орієнтовані на внутрішній ринок, спеціалізуються на виробництві дрібних партій трудомісткої продукції рослинництва та садівництва, вирощують овочі, ягоди, а також займаються птахівництвом, бджолярством, молочарством, розводять свійські тварини у невеликих (порівняно з промисловими) маситабах. Фермери розвинутих країн світу (насамперед - ЄС), спеціалізуються на виробництві органічної продукції, що має гарантований попит у представників середнього класу. В країнах ЄС фермерство традиційно має державну підтримку, оскільки несе у собі як економічну, так і вагому соціальну фрнкцію - підтримує розвиток сільських територій та створює робочі місия у сільській місцевості. Найбільшими «аравцями» на ринку масового виробництва аграрної продукції у світі вважаються великі національні та міжнародні агрохолдінги, ТНК, що спеціалізуються на масовому виробництві аграрної продукції та на її індустріальній переробці. ТНК створили замкнений цикл - від селекції до виробництва аграрної продукції, від ії̈ переробки до виробництва готової продукції. За рахунок великих маситабів виробництва, концентрації та централізації капіталу саме аграрні ТНК займають лідируючі позиції у виробництві та експорті аграрної продукції на світових ринках. Лідерство ТНК на світових аграрних ринках грунтується на стратегії реалізації «зеленої революції», складовими якої є інноваційні технології, біо-селекція для виведення високопродуктивних порід тварин, для інтенсивного зростання врожайності рослинництва, у т.ч. із застосуванням ГМО (що зробить рослинництво «не чутливим» до дефріциту води, до високих температур та посухи). Аграрні ТНК у XXI cm. активно впроваджують стратеаії переходу до високоточного аграрного виробництва на основі використання інноваційних та IT-технологій.

Як свідчить світовий досвід, стратегії переходу до високоточного аграрного виробництва поєднують у собі наступні інновації: космічні та авіаційні технології, безпілотні технології, безпілотні літальні апарати (БПЛА); масовий перехід до використання апаратури онлайн-аналізу ґрунту; поширення інноваційних технологій «агроскаутингу» щодо оперативного збору інформації про стан та розвиток аграрного виробництва; впровадження інтелектуальних систем підтримки прийняття управлінських рішень, запровадження автоматизованої системи моніторингу та контролю, впровадження IT-систем обліку всіх складових процесів аграрного виробництва. Розвиток високоточного аграрного виробництва для національної економіки країн, що мають аграрну спеціалізацію має низку переваг, а саме: зростання продуктивності праці у аграрному секторі; скорочення кількості зайнятих, що заощаджує оборотні кошти агрофрірм; індустріалізація та технічне переоснащення аграрного сектору, що створює ринок збуту для IT-продукції, високоточного 
машинобудування; збільщення товарності та експортного потенціалу країни, в основному - у сфері моноструктурного виробництва продукції рослинництва (зернові, кукурудза, соя, рапс, олійні культури та ін.). Такі стратегії передбачають й активізацію процесів прямого іноземного інвестування ТНК у скуповування земель сільськогосподарського призначення в країнах, що розвиваються з наступним їх «включенням» як постачальників сировини для ТНК, що формують та контролюють міжнародні ланцюги виробництва доданої вартості всіх видів аграрної продукції.

Серед ризиків, що несе з собою впровадження стратегій високоточного аграрного виробництва для національної економіки країн, що розвиваються та які мають аграрну спеціалізацію - слід назвати наступні: ризики щодо скорочення кількості фермерських господарств та скорочення обсягів виробництва трудомісткої, дрібнотоварної аграрної продукції (овочі, фррукти, мед та ін.); ризики скорочення кількості робочих місць та, відповідно, кількості мешканців сільських територій та ін. Серед пов'язаних з такими процесами - ризики зростання обсягів імпорту готових продуктів харчування, хронічний дефріцит державного бюджету та зростання зовнішнього боргу (внаслідок дефіциту валюти), посилення міграційних процесів та ін. У випадку падіння світових цін на продукти харчування та погіршення світової кон'юнктури на аграрну продукцію (у т.ч. на аграрну сировину, наприклад - внаслідок настання чергової світової економічної кризи), не слід виключати і штучне «виведення» придбаних ТНК земель в аграрних країнах, що розвиваються, з обороту, їх наступне «заморожування» та припинення обробки «до кращих часів». За таких обставин серед ймовірних ризиків щодо втілення такої стратедії ТНК слід назвати ризики голоду для країн, що втратять контроль управління над власними земельними ресурсами.

Галузь застосування результатів. Міжнародні економічні відносини та світове господарство; розробка конкурентних стратегій аграрного виробництва країн світу та аграрних ТНК у світовій економіці.

Висновки відповідно до статmі. "Економічними чентрами» масового аграрного виробництва в усіх країнах світу є: фрермерські господарства та агрохолдінги (агрофрірми), аграрні ТНК. Фермерські господарства спеціалізуються, в основному, на виробництві дрібнотоварної аграрної трудомісткої продукції-овочеводство, садівництво, бджолярство та ін. Великі агро-фрірми та аграрні ТНК обирають стратегію спеціалізації на масовому виробництві моноструктурної аграрної продукції (в основному, рослинництва: зерно, кукурудза, соя, аграрні технічні культури).

У розвинених країнах світу ТНК використовують стратегії багатоиільового використання сільськогосподарських земель, у т.ч. для цілей розвитку та переробки продукції тваринництва, рослинництва; для розвитку відновлюваної енергетики, біоенергетики. У розвинених країнах світу ТНК зорієнтовані на переробку всіх видів аграрної продукиії та на виробництво готових продуктів харчування з високим вмістом доданої вартості. Для ТНК придбання сільськогосподарських земель в країнах, що розвиваються (у т.ч. за рахунок ПІІ), дозволяє втілити стратеаію долучення придбаних земель, в основному, для розвитку рослинництва як сировинної бази для ї подальшої переробки в країнах походження ТНК.

Загальносвітовим трендом розвитку аграрних ТНК стає застосування інноваційних технологій, перехід до високоточного аграрного виробництва з використанням IT-технологій, авіаційних та космічних технологій, безпілотних літальних апаратів та інших інновацій, що позитивно позначається на продуктивності праці та рентабельності масового індустріального виробництва, але створює низку соціальних ризиків для економіки країн, що розвиваються і які мають пріоритетом перехід до моноструктурної аграрної спеціалізації.

Перехід українських агрофрірм та агрохолдінгів до стратегії розвитку високоточного аграрного виробництва на основі інноваційних та IT-технологій забезпечить для України конкурентоспроможність на світовому ринку аграрної продукції. Цей процес має супроводжуватися проведенням земельної рефрорми з урахуванням інтересів розвитку українського фермерства. Стратегією для України має стати налагодження у сфрері національного виробництва індустріальної переробки аграрної сировини та виробництво готових продуктів харчування з високим вмістом доданої вартості.

Ключові слова: стратегії, аграрне виробництво, фермерство, транснаціональні корпорації (ТНК), прямі іноземні інвестиції (ПІІ), земельні ресурси, «зелена революція», високоточне аграрне виробництво, інновації, ІТ-технології.

\section{СТРАТЕГИИ ПРОИЗВОДСТВА АГРАРНОЙ ПРОДУКЦИИ: МИРОВОЙ ОПЫТ}

Белая С. А.

Актуальность темы исследования. Ликвидация голода и обеспечение населения планеты Земля достаточным количеством продовольствия было признано ООН одним из стратегических приоритетов устойчивого развития человеческой цивилизации на период до 2030 года. С увеличение количества населения планеты Земля, которое на настоящий момент превышает 7,6 млрд. человек, в XXI cm. стремительно растет глобальный спрос на продовольствие и продукты питания. В тоже время, традиционные для XX cm. стратегии экстенсивного развития и «точечной» интенсификации аграрного производства в современных условиях не дают ожидаемых позитивных результатов. Для мировой экономики нужны новые стратегии развития аграрного производства, реализация «зеленой революции» с использованием преимуществ IT-технологий и «Индустрии 4.0». Обобщение мирового опыта о разработках и внедрении стратегий производства аграрной продукции в XXI cm. имеет 
существенное теоретическое и практическое значение для всех стран, массово экспортирующих аграрную продукцию, а также и для Украины, ориентированной на лидерство в мировом аграрном производстве. Такая постановка проблемы свидетельствует об актуальности данной статьи.

Постановка проблемы. Увеличение объёмов производства продовольствия в мировой экономике происходит медленно и не удовлетворяет возрастающий спрос на продукты питания и на аграрное сырьё для индустриально-промышленного комплекса в мировых маситабах. В таких условиях производители товарной аграрной продукции - фрермеры, агро-фирмы и агрохолдинги, ТНК - меняют подходы и модифицируют традиционные для XX cm. стратегии аграрного производства. Лидирующие позиции среди новых стратегий занимает переход к высокоточному земледелию и инновационному аграрному производству на основе использования потенциала IT-технологий. Содержание и социальноэкономические последствия внедрения такой стратегии требуют детального исследования.

Анализ последних исследований и публикаций. Существенный вклад в исследование сущности и направленности стратегий аграрного производства в их связи с инновационно-инвестиционным развитием и с усовершенствованием отношений собственности осуществили украинские учёные Макаренко П. М., Пилявский В. И. [1] и Шульга О. А. [2]. Иностранные ученые, такие как: К. Смаллер, У. Спеллер, Х. Мирза, Н. Бернаскони-Остервальдер, Г. Дикси и др. [3] особое внимание уделяли исследованию стратегических приоритетов минимизации рисков и максимизации прибыли агро-фрирм и THK в процессе реализации аграрных контрактов на мировых рынках. Иностранные ученые Б. Кеатинг, М. Херреро, П. Карберри [4] в своих исследованиях акцентировали внимание на актуальности соблюдения стратегий обеспечения продовольственной безопасности в глобальной среде. В тоже время, остаётся не исследованным вопрос о разработке стратегий высокоточного аграрного производства с массовым использованием инноваций и IT-технологий, исследование социально-экономических последствий, которые сопровождают их внедрение в XXI cm.

Выделение неисследованных частей общей проблемы. Проблематика исследования сущности и составляющих процессов развития аграрного производства в мировом хозяйстве достаточно полно освещены в мировой экономической литературе. В тоже время, для определения стратегических приоритетов развития аграрного производства особое значение приобретает исследование стратегий деятельности ТНК и фрермерских хозяйств, стратегий перехода ТНК к развитию высокоточного аграрного производства. Неопределенными на сегодняшний момент являются тенденции ПИИ в сфере покупки земель сельскохозяйственного назначения и анализ приоритетов их использования ТНК в развитых странах мира и в развивающихся странах. Детального исследования требуют и социально-экономические последствия массового внедрения высокоточного аграрного производства для национальной экономики стран, имеющих аграрную специализацию.

Постановка задачи, цели исследования.

Цель исследования - определить сущность, выявить закономерности фрормирования и обосновать основные ожидаемые социально-экономические последствия внедрения стратегий развития высокоточного аграрного производства (на примере обобщения мирового опыта деятельности аграрных ТНК).

Для достижения цели в статье поставлены и рассматриваются следующие задания:

- определить основных «игроков» на мировом аграрном рынке и исследовать приоритеты их экономической деятельности;

- исследовать сущность и составляющие стратегии «зеленой революции», стратегии перехода к высокоточному аграрному производству на основе использования инновационных и IT-технологий;

- определить стратегические цели ТНК по использованию приобретенных земель (за счет прямых иностранных инвестиций) на примере обобщения опыта развитых стран мира и развивающихся стран;

- определить ожидаемые социально-экономические последствия массового внедрения стратегий высокоточного аграрного производства ТНК, а также национальным агробизнесом для экономики стран, имеющих аграрную специализацию.

Метод или методология проведения исследования. В процессе исследования мирового опыта внедрения стратегий развития высокоточного аграрного производства использовались теоретические и эмпирические методы научных исследований. В статье использованы методы исторического и логического, анализа и синтеза, абстрактного и конкретного, метод причинно-следственных связей для определения стратегических приоритетов специализации фермерских хозяйств и аграрных ТНК, для определения ожидаемых социально-экономических последствий массового перехода к высокоточному аграрному производству стран, имеющих аграрную специализацию. Синергетический подход, метод экспертных оценок, каузальный (причинно-следственный) метод научных исследований был задействован для обоснования стратегий «зелёной революции», стратегий ТНК по переходу к высокоточному аграрному производству на основе использования инновационных и IT-технологий.

Изложение основного материала (результаты работы).

В сфрере аграрного производства представлены: фермеры, домашние хозяйства, государственный аграрный сектор, национальные агрофирмы и агрохолдинги, интернациональные ТНК. Фермерские хозяйства, как правило, ориентированы на внутренний рынок, специализируются на производстве мелких партий трудоемкой продукции растениеводства и садоводства, выращивают овощи, ягоды, а 
также занимаются птицеводством, пчеловодством, производством молочной продукции, разводят домашних животных в небольших (по сравнению с промышленным) масштабах. Фермеры развитых стран мира (прежде всего - EC), специализируются на производстве органической продукции, что имеет гарантированный спрос у представителей среднего класса. В странах ЕС фермерство традиционно получает государственную поддержку, поскольку несет в себе как экономическую, так и важнейшую социальную функцию - поддерживает развитие сельских территорий и создает рабочие места в сельской местности. Наисильнейшими "игроками» на рынке массового производства аграрной продукции в мире считаются крупные национальные и международные агрохолдинги, ТНК, которые специализируются на массовом производстве аграрной продукции и на её индустриальной переработке. ТНК создали замкнутый цикл - от селекции до производства аграрной продукции, от ее переработки до производства готовой продукции. За счет больших масштабов производства, концентрации и централизации капитала именно аграрные ТНК занимают лидирующие позиции в производстве и экспорте аграрной продукции на мировых рынках. Лидерство ТНК на мировых аграрных рынках основывается на стратегии реализации «зелёной революции», составляющими которой являются инновационные технологии, био-селекция для выведения высокопродуктивных пород животных, а также для интенсивного роста урожайности растениеводства, в т.ч. с использованием ГМО (что делает растениеводство «не чувствительным» $к$ дефициту воды, к высоким температурам и засухам). Аграрные ТНК в XXI cm. активно внедряют стратегии перехода к высокоточному аграрному производству на основе использования инновационных и IT-технологий.

Мировой опыт свидетельствует, что стратегии перехода к высокоточному аграрному производству объединяют в себе следующие инновации: космические и авиационные технологии, беспилотные технологии, беспилотные летательные аппараты (БПЛА); массовый переход к использованию аппаратуры онлайн-анализа почвы; распространение инновационных технологий «агроскаутинга» по оперативному сбору информации о состоянии и развитию аграрного производства; внедрение интеллектуальных систем поддержки принятия управленческих решений, внедрение автоматизированной системы мониторинга и контроля, внедрение IT-систем учета всех составляющих процессов аграрного производства. Развитие высокоточного аграрного производства для национальной экономики стан, имеющих аграрную специализацию, имеет ряд преимуществ, в том числе: рост производительности труда в аграрном секторе; сокращение количества занятых, что экономит оборотные средства агрофирм; индустриализация и техническое переоборудование аграрного сектора, что создаёт рынок сбыта для IT-продукции, высокоточного машиностроения; увеличение товарности и экспортного потенциала страны, в основном - в сфере моноструктурного выращивания продукции растениеводства (зерновые, кукуруза, соя, рапс, масличные культуры и др.). Такие стратегии предусматривают и активизацию процессов прямого иностранного инвестирования ТНК в целях покупки земель сельскохозяйственного назначения в развивающихся странах с последующим их «включением» как поставщиков сырья для ТНК, формирующих и контролирующих международные цепочки производства добавочной стоимости всех видов аграрной продукции.

Среди рисков, связанных с внедрением стратегий высокоточного аграрного производства для национальной экономики развивающихся стран, имеющих аграрную специализацию - следует назвать следующие: риски сокращения количества фермерских хозяйств и сокращения объёмов производства трудоёмкой, мелкотоварной аграрной продукции (овощи, фррукты, мед и др.); риски сокращения количества рабочих мест и, соответственно, сокращение количества жителей сельских территорий и др. Среди связанных с вышеназванными - риски увеличения объёмов импорта готовых продуктов питания, хронический дефицит государственного бюджета и рост внешнего долга (вследствие дефицита валюты), рост миграционных процессов и другие риски. В случае падения мировых цен на продукты питания и ухудшения мировой конъюнктуры на аграрную продукцию (в т.ч. на аграрное сырьё, например - вследствие начала очередного мирового экономического кризиса), не следует исключать и искусственное «выведение» приобретенных ТНК земель в развивающихся аграрных странах из оборота и их последующее «замораживание», прекращение обработки приобретенных земель «до лучших времен». В данном случае, среди вероятных рисков реализации такой стратегии ТНК, следует назвать риски голода для стран, утративших контроль управления над собственными земельными ресурсами.

Область применения результатов. Международные экономические отношения и мировое хозяйство; разработка конкурентных стратегий аграрного производства стран мира и аграрных ТНК в мировой экономике.

Выводы в соответствии со статьей. "Экономическими центрами» массового аграрного производства во всех странах мира являются: фермерские хозяйства и агрохолдинги (агрофирмы), аграрные ТНК. Фермерские хозяйства специализируются, в основном, на производстве мелкотоварной аграрной трудоемкой продукции - овощеводство, садоводство, пчеловодство и др. Крупные агрофрирмы $и$ аграрные ТНК выбирают стратегию специализации на массовом производстве моноструктурной аграрной продукции (в основном, растениеводство: зерно, кукуруза, соя, аграрные технические культуры). 
Выводы в соответствии со статьей. В развитых странах мира ТНК используют стратегии многоцелевого использования сельскохозяйственных земель, в т.ч. в целях развития и переработки продукции животноводства, растениеводства; для развития возобновляемой энергетики, биоэнергетики. В развитых странах мира ТНК ориентированы на переработку всех видов аграрной продукции и на производство готовых продуктов питания с высоким удельным весом добавочной стоимости. Для ТНК приобретение сельскохозяйственных земель в развивающихся странах (в т.ч. за счет ПИИ), позволяет реализовать стратегию использования приобретенных земель, в основном, для развития растениеводства как сырьевой базы для её дальнейшей переработки в странах происхождения ТНК.

Общемировым трендом развития аграрных ТНК становится использование инновационных технологий, переход к высокоточному аграрному производству с использованием IT-технологий, авиационных и космических технологий, беспилотных летательных аппаратов и других инноваций, что позитивно отобразится на производительности труда и рентабельности массового индустриального производства, но создаст целый ряд социальных рисков для экономики развивающихся стран, признавщих в качестве приоритета переход к моноструктурной аграрной специализации.

Переход украинских агрофрирм и агрохолдингов к стратегии развития высокоточного аграрного производства на основе инновационных и IT-технологий обеспечит для Украины конкурентоспособность на мировом рынке аграрной продукции. Этот процесс должен сопровождаться проведением земельной реформы с учётом интересов развития украинского фермерства. Стратегией для Украины может стать развитие в сфрере национального производства индустриальной переработки аграрного сырья и производство готовых продуктов питания с высоким удельным весом добавочной стоимости.

Ключевые слова: стратегии, аграрное производство, фермерство, транснациональные корпорации (ТНК), прямые иностранные инвестиции (ПИИ), земельные ресурсы, «зелёная революция», высокоточное аграрное производство, инновации, IT-технологии.

\section{AGRICULTURAL PRODUCTION STRATEGIES: WORLD EXPERIENCE}

Bila Svitlana

Actual importance of research theme: Combating hunger and providing the Earth's population with sufficient amount of products is considered one of the strategic priorities of human civilization sustainable development by the UN up to 2030. The rapid growth of this planet's human population in the 21st century, estimated at 7.6. billion people, leads to the global demand for production and foodstuff. Simultaneously, traditional strategies of extensive development conventional in the 20th century and «target» intensification of agriculture do not take expected positive effect nowadays. World economy requires for new strategies of agricultural production, as well as promoting 'green revolution' based on the ground of IT technology advances and "Industry 4.0.». The generalization of world experience concerning development and implementing agricultural production strategies in the 21st century is of greater theoretical and practical importance for all countries which export agricultural production in mass scales, including Ukraine which focuses on the leadership in the world agricultural business. Thus, the urgency of the issue confirms the actual importance of this article.

The problem statement. Foodstuff output in world economy is growing slowly and does not meet the increasing demand for food and agricultural products in industry in global scales. Under these conditions the manufacturers of agricultural products like farmers, agro-businesses and agro-holdings, as well as transnational corporation alter and modify agricultural strategies that were conventional in the 20th century. Among the new strategies transition to precision farming and innovational agriculture based on implementing IT technologies takes the leading role. The core and socio-economic consequences of such strategy implementation require further study.

Analysis of latest studies and publication. The important contribution to the study of the core and dimensions of agricultural production strategies linked to innovation and investment development as well as to improvement property relations is made by such Ukrainian scholars as P. Makarenko, V. Pilyavskiy [1] and O. Shul'ga [2]. Foreign scientists like Smaller, C., and W. Speller, with H. Mirza, N. Bernasconi-Osterwalder, and G. Dixie [3] paid the specific attention to the study of strategic priorities concerning risks minimization and profit maximization by agrobusinesses and TNC within the realization of agricultural contracts at world markets. Overseas researchers Keating B., Herrero M., Carberry P. [4] emphasized on actual importance of compliance with strategy of foodstuff security in global environment in their studies. However, the issue of developing the strategy of precise agricultural production based on widespread use of innovation and IT technologies, research into socio-economic consequences accompanying their implementation in the 21 st century remains poorly studied.

Research challenge of general issue. The issue of studies the core and elements of agricultural production development process in world economy is highlighted in world economic literature pretty well. Nevertheless, the study of TNCs and agricultural businesses strategies and strategies concerning transition of TNCs to the development of precise agriculture is really meaningful. Besides, at present time the trends of direct foreign investments as for agricultural lands purchase and priorities analysis of their use by TNCs in developed and developing world countries are uncertain. Socio economic consequences of mass precise agriculture introduction for national economy in countries with agrarian specialization also require detailed researching.

Problem statement, objective of research. 
The objective of research is to highlight the core and define the regularity of formation, as well as emphasize the basic expected socio-economic consequences of precise agriculture development strategy implementing on the grounds of generalization the world experience of agricultural TNC sactivity.

To achieve the objective set the article aimed at solution the following tasks:

- to note the main 'players' at the world agricultural market and study the priorities of their economic activity;

- to study the core and the elements of 'green revolution' strategy, as well as strategy of transition to precise agricultural production based on implementing innovations and IT technologies;

- to define strategic goals of TNCs as for the use of acquiring land ( at the cost of direct foreign investments) on the grounds of generalization developed and developing countries experience;

- to point out the expected socio-economic consequences of mass implementation of precise agricultural production strategies by TNCs and national agro-businesses for the economy of the countries specialized in agriculture.

Method and methodology of the study. While studying the world experience of implementation the precise agricultural production development strategies theoretical and empirical methods of scientific research were employed. Historical and logical methods, abstract and specific methods, methods of analysis and synthesis, as well as causal (cause-and-effect) method were applied in the article to define strategic priorities of agricultural business and agricultural TNC specialization, to point out expected socio-economic consequences of mass transition to precise agricultural production in the countries with agrarian specialization. Synergetic approach, method of expert estimates and casual methods were applied to ground "green revolution» strategy, as well as strategy of TNCs as for transition to precise agriculture based on innovations and IT technologies.

The results of study. Agricultural production is presented by farmers, households, state agricultural sector, national agro-businesses and agro-holdings, international TNCs. As a rule, farms are focused on domestic market; they specialize in production of minor parties of manual crop production and horticulture, grow vegetables, fruit and berries, as well as they are engaged in poultry farming, beekeeping, dairy production, stockbreeding in rather small scales. The farmers in developed world countries, particularly EU countries, concentrate on organic production which is of high demand among middle-class representatives. In EU countries farming is traditionally supported by the state, as it bears both economic and social valuable functions, i.e. assists in rural development and creates workplaces in countryside. The main stakeholders at the mass agricultural market in the world are considered large national and international agro-holdings an TNCs specialized in agricultural production and its industrial processing. TNCs shaped the closed loop - from selection to agricultural production, from its processing to its manufacturing. At the cost of large production scales, as well as capital concentration and centralization it is the agricultural TNCs which leads in production and export of foodstuffs at world markets. TNCs 'leadership at world agriculture markets is grounded on 'green revolution' strategy implementing, which consists of such elements as innovations, bio-selection to produce performance breed, intensive growth in crop productivity, including the one using GMO which makes cropping insensitive to water shortage, high temperatures and droughts. Agrarian TNCs in the 21st century actively implement the strategies of transition to precise agriculture based on the use of innovations and IT technologies.

As the world experience confirms, strategies of transition to precise agriculture combine the following innovations: astronaut and aviation technologies, unmanned technologies, unmanned aerial vehicles; mass transition to the use of apparatus to analyze the ground online; spreading of "agro-scouting" innovation technologies as for field information gathering concerning the condition and development of agriculture; implementation intellectual system of managerial decision-making support; introduction of monitoring and control auto-system and implementation of IT-system as for account of agriculture process elements. The development of precise agriculture for national world economies which are agriculture-based offers a lot of benefits, such as: increase in labor productivity in agriculture; the decrease in employment that saves working capital of agrobusinesses; industrialization and technical renovation of agrarian sector which promotes the market for IT products, precise machine building; increase in commerce and export potential of the country, mainly, in the sphere of monostructural crop production (grain, corn, soya, raps, oilseeds etc.). Such strategies also provide revitalization of direct foreign investment processes by TNCsconcerning purchasing farmland in the developing countries with their further listing as raw materials supplier for TNCs. The latter shape and control international links of production value added to all kinds of agricultural products.

Among the risks which implementation of precise agriculture strategies bear for national developing country's economy which are agriculture-based the following should be mentioned: risks concerning decrease in farms and decline in production of labor-intensive small-scale agriculture products (vegetables, fruit, honey etc.); risks of jobs recession and, respectively, the number of rural population and others. There are also other risks linked to these processes like risks of growing volumes of ready foodstuffs import, chronic scarcity of state budget and increase in internal debt, enhancing migration processes etc. In case of falling world prices for foodstuffs and worsening global conditions for agriculture products, including agrarian raw materials, in particular, due to another world economic crisis, the abandonment of occasional farmland purchased by TNCs in developing agrarian countries, their further freezing and ceasing the processing for better times should not be excluded. Under such circumstances the risks of famine for countries which could lose the managerial control over own land resources are also a threatening exercise as for implementing such TNC strategy. 
The field of results application. International economic relations and world economy, development of agriculture competitive strategies in world countries and agrarian TNCs in world economy.

Conclusions. Farms, agro-businesses, agro-holdings and agrarian TNCs are the economic centres of mass agriculture production in all world countries. Farms are mainly specialized in labour-intensive small-scale agriculture production like horticulture, gardening, bee-keeping etc. Large agro-businesses and agrarian TNCs choose the strategy of specializing in mass monostructural agriculture production such as crop production (grain, corn, soya beans and industrial crops).

In developed world countries TNCs apply the strategy of farmlands multi-purpose use, including the goals aimed at development and processing livestock and crop production; at development of renewable energy and bio-energy. In developed world countries TNCs focus on processing all kinds of agriculture products and foodstuffs production with high value added. Purchasing of farmlands by TNCs in developing countries, in particular, at the cost of direct foreign investment, provides for implementation the strategy of purchased lands engagement, mainly, to develop crop production as a raw basis for their further processing in the native countries for TNCs.

The general world trend of agrarian TNCs development is use of innovation technologies, transition to precise agriculture based on IT technologies, aviation and astronautic technologies, unmanned aerial vehicles and other innovations which positively impact labor productivity and mass industrial production profitability, as well as choose transition to monostructural agrarian specialization as a priority, but bear a set of social risks for developing countries' economies.

Transition of Ukrainian agro-businesses and agro-holdings to the strategy of precise agriculture development based on innovations and IT technologies provides Ukraine's competitiveness at the world agrarian markets. This process should go hand-in-hand with land reform taking into account Ukrainian farming interests. Establishing industrial processing of agriculture raw products and production of ready foodstuffs with high value added should be strategic for Ukraine.

Key words: strategies, agriculture production, farming, transnational corporations (TNCs), direct foreign inverstments (DFI), land resources, 'green revolution', precise agriculture, innovations, IT technologies.

JEL Classification: F01, N5, Q18

Актуальність теми дослідження. Подолання голоду та забезпечення населення планети Земля достатньою кількістю продовольства визнано ООН серед головних стратегічних пріоритетів сталого розвитку людської цивілізації у XXIст. Із зростанням кількості населення планети Земля, яке нині перевищує 7,6 млрд осіб, стрімко зростає і глобальний попит на продовольство та продукти харчування. Натомість, зростання обсягів виробництва продовольства підпадає під ризик та гальмується впливом глобального потепління та зміною клімату, що призводить до різких змін температурних режимів, до затоплення прибережних, як правило - аграрних територій, збільшує кількість паводків та посух, обумовлює зростання десріциту прісної води. В таких несприятливих умовах виробники товарної агарної продукції - фермери та великі агрохолдінги, аграрні ТНК - змінюють та модифікують традиційні стратегії аграрного виробництва, притаманні XX ст., пристосовуються до нових умов господарювання. Лідером серед нових стратегій $€-$ задіяння потенціалу ITтехнологій, здобутків високоточного землеробства та інноваційного аграрного виробництва. Узагальнення світового досвіду щодо розробки та впровадження стратегій виробництва аграрної продукції має вагоме теоретичне та практичне значення і для України, яка претендує на лідерство у світовому аграрному виробництві але і досі не має цивілізованого ринку землі та офріційної державної стратегії розвитку аграрного виробництва. Така постановка проблеми свідчить про актуальність теми даної статті.

Постановка проблеми. Зростання обсягів виробництва продовольства у світовій економіці відбувається повільно і не задовольняє зростаючий попит на продукти харчування та на аграрну сировину для промислового комплексу. В таких умовах виробники товарної аграрної продукції - фермери та великі агрохолдінги, аграрні ТНК - змінюють та модифікують традиційні для XX ст. стратегії аграрного виробництва. Лідирують серед нових стратегій ті, які тісно пов'язані із впровадженням високоточного землеробства, ITтехнологій та інноваційного аграрного виробництва, що потребує докладного дослідження.

Аналіз останніх досліджень та публікацій. Вагомий внесок у дослідження сутності та спрямованості стратегій агарного виробництва у їх зв'язку з інноваційно-інвестиційним розвитком та з удосконаленням відносин власності здійснили українські вчені Макаренко П. М., Пілявський В. І. [1] та Шульга О. А. [2]. Іноземні вчені, такі як: К. Смаллер, У. Спеллер, Х. Мірза, Н. Бернасконі-Остервальдер, Г. Діксі та ін. [3] особливу увагу приділяють стратегічним пріоритетам щодо мінімізації ризиків та максимізації прибутків в процесі реалізації аграрних контрактів на світових ринках. Іноземні вчені Б. Кеатінг, М. Херреро, П. Карберрі [4] у своїх дослідженнях наголошують на актуальності дотримання стратегій забезпечення продовольчої безпеки у глобальному середовищі.

Виділення недосліджених частин загальної проблеми. Проблематика дослідження сутності та складових процесу розвитку аграрного виробництва у світовому господарстві достатньо повно висвітлена у світовій економічній літературі. Натомість, для визначення стратегічних пріоритетів розвитку аграрного виробництва особливого значення набуває дослідження стратегій діяльності ТНК та фермерських господарств, стратегій переходу ТНК до розвитку високоточного аграрного виробництва. Невизначеними на сьогодні $\epsilon$ тенденції ПII щодо купівлі земель сільськогосподарського призначення та аналіз пріоритетів їх використання ТНК у розвинутих країнах світу та в країнах, що розвиваються. 
Постановка завдання, мети дослідження.

Мета дослідження - висвітлити сутність та визначити закономірності формування конкурентних стратегій розвитку аграрного виробництва у світовому господарстві (на прикладі діяльності аграрних ТНК).

Для досягнення мети у статті поставлені та вирішуються наступні завдання:

- визначити основних «гравців» на світовому аграрному ринку та дослідити пріоритети їх аграрної спеціалізації;

- дослідити сутність та складові стратегії «зеленої революції», складовими якої визнано IT- технології та інші аграрні інновації;

- обґрунтувати спрямованість стратегій ТНК щодо розвитку високоточного аграрного виробництва та стратегій використання придбаних земель за рахунок ПІІ у розвинених країнах світу та у країнах, що розвиваються.

\section{Метод або методологія проведення дослідження.}

В процесі дослідження світового досвіду стратегій виробництва аграрної продукції використовувалися теоретичні та емпірічні методи наукових досліджень. У статті було використано методи історичного та логічного, аналізу та синтезу, абстрактного та конкретного, метод причинно-наслідкових зв'язків для визначення стратегічних пріоритетів спеціалізації фермерських господарств та аграрних ТНК. Синергетичний підхід, метод експертних оцінок, каузальний (причинно-наслідковий) метод наукових досліджень було використано для обґрунтування стратегій «зеленої революції», стратегій ТНК щодо розвитку високоточного аграрного виробництва на основі використання інноваційних та IT-технологій.

Викладення основного матеріалу (результати роботи). У сфері агарного виробництва традиційно представлені: фермери, домашні господарства, державний аграрний сектор та великі агрохолдінги, вищою формою існування яких $€$ ТНК. У кожного з учасників аграрного виробництва $є$ цілі та пріоритети розвитку. Так, домашні господарства, в основному, забезпечують себе аграрною продукцією (на кшталт натурального виробництва) і лише частково продають вироблену на власних присадібних ділянках продукцію дрібними партіями на місцевих ринках. У економіці цей сектор часто відносять до «сірої», не облікованої економіки.

Фермери у кожній країні світу, яка дбає про аграрне виробництво, займають особливу нішу. Фермерство несе у собі як економічну, так і соціальну функцію. Фермерські господарства, як правило, спеціалізуються на виробництві трудомісткої продукції рослинництва та садівництва, вирощують овочі, ягоди, а також займаються птахівництвом, бджолярством, розводять свійські тварини у невеликих (порівняно з промисловими) масштабах. Фермери розвинутих країн світу спеціалізуються на виробництві органічної продукції, що гарантує її збут. Держава надає фермерам підтримку, у т.ч. субсидії та дотації, надає їм можливість отримати пільгові кредити. Адже підтримка фермерства - це підтримка і сільських територій, збереження робочих місць на селі та утримання місцевих мешканців на постійному місцепроживанні у селах. В Україні фермери, як правило, виробляють агарну продукцію на площах від 500 га, а за наявності сільськогосподарської техніки - на землях площею 3 - 5 тисяч гектар.

Державні землі сільськогосподарського призначення мають місце у всіх країнах світу, які дбають про національну безпеку та національну економічну безпеку як її складову. Державний земельний фонд у країнах з ринковою економікою варіюється від 10 до 50 \% та вище. Наприклад, в самих ліберальних щодо продажу земель сільськогосподарського призначення країнах, обсяг земель, що залишається у власності держави, становить: в Канаді - 35 \%, у США - біля 7 \%, в Австралії - біля 23 \% площ земель сільськогосподарського призначення. При цьому питома вага агросектору у структурі ВВП цих країн (2017 р.) коливається у межах від 1,5 - до 3 \%, а кількість зайнятого населення у аграрному виробництві не перевищує 1,2 - 3,6 \%, до 4 \% від загальної кількості економічно активного населення [5; 6].

Вважається, що тільки у авторитарних країнах та країнах з низьким рівнем розвитку ринкових відносин зберігається мораторій на продаж земель (Куба, КНДР, Конго, Венесуела, Таджикистан). У Білорусії 98 \% землі належить державі. Також, заборонено продаж землі в Ізраїлі, що хронічно перебуває під впливом ризику загострення локальних військових конфліктів. Для переважної більшості країн світу продаж земель сільськогосподарського призначення має обмеження. Найбільш поширені серед таких обмежень: продаж земель с/г призначення тільки громадянам країни, тільки фермерам, фрізичним та юридичним особам, що мають практичний досвід роботи у аграрному виробництві (не менше 5-8 років), відповідну аграрну освіту та спеціалізацію. У країнах з розвиненим місцевим самоврядуванням саме місцевим громадам надаються повноваження вирішувати - які обсяги земель с/г призначення можна продавати в одні руки.

Найбільшими «гравцями» на ринку виробництва аграрної продукції у світі вважають великі національні та міжнародні агрохолдінги та ТНК, що спеціалізуються на масовому виробництві аграрної продукції та на її переробці.

Серед лідерів світового аграрного виробництва перебувають, насамперед, ТНК, що спеціалізуються на рослинництві (зерно, кукурудза, соя, рапс, пальмові плантації для виробництва пальмової олії, вирощування інших технічних культур) та на індустріальному розвитку тваринництва та птахівництва (розведення великої рогатої худоби та молочарство; промислове розведення свиней та інших видів свійських тварин; птахівництво - кури, індики, гуси та ін.). ТНК, як правило, організовують замкнений виробничий аграрний цикл - від сировини до її переробки та виробництва готової продукції, у т.ч. на експорт. За рахунок великих масштабів виробництва, концентрації та централізації капіталу саме аграрні ТНК займають лідируючі позиції у виробництві та експорті аграрної продукції на світових ринках. В основі стратегій діяльності аграрних ТНК - «зелена революція» та 
капіталізація процесів аграрного виробництва (що найбільшою мірою спостерігається в країнах розташування материнських компаній ТНК). Для аграрних ТНК, що представляють інтереси розвинутих країн світу (США, країн $€ C)$, набуває актуальності і стратегія «поширення економічного впливу та отримання додаткової сировинної аграрної бази» в країнах, що розвиваються, в таких країнах, які мають багатий аграрний потенціал та водні ресурси, але брак капіталів. У сферу інтересів ТНК щодо застосування останньої стратегії потрапляє й Україна. Ця проблема потребує окремих наукових досліджень та не є предметом дослідження даної статті.

У світовій практиці безумовне лідерство ТНК на світових аграрних ринках ґрунтується на стратегії реалізації так званої «зеленої революції», складовими якої називають, насамперед, інноваційні технології та роботу у сорері біо-селекції для виведення більш продуктивних порід тварин та для зростання врожайності у сорері рослинництва. Одним з різновидів такої стратегії вважають і продукування генно-модифікованого посівного матеріалу, стійкого до посухи, до шкідників та до хронічного дефіциту прісної води. Натомість, селекція щодо виведення нових, продуктивних сортів сільськогосподарських культур відбувається як із застосуванням, так і без застосування технологій виведення генно-модифікованих організмів (ГМО). Так, в країнах ЄС розповсюдження ГМО жорстко контролюється державою, а в більшості європейських країн взагалі заборонено.

Другою складовою «зеленої революції» $€$ розвиток іригації, розповсюдження інноваційних іригаційних систем та технологій, у т.ч. систем крапельного зрошування, гідропоніки, «вертикальних фрерм» та ін. Цей напрямок $є$ надзвичайно важливим, оскільки нові сорти зернових культур зможуть нарощувати врожайність лише в умовах стабільного та доступного водозабезпечення, адже в умовах глобального потепління та зміни клімату у XXI ст. дефіцит води стає основною загрозою для продуктивності сільського господарства.

Третя складова «зеленої революції» - широке впровадження інновацій у аграрному виробництві, масова індустріалізація всіх процесів щодо розвитку сільського господарства, у т.ч. 3 використанням ІТтехнологій, дронів, авіаційних та космічних технологій, NBIC- технологій та робототехніки.

У XXI ст. інтенсифрікація аграрного виробництва у країнах-лідерах світового розвитку відбувається у напрямі скорочення витрат на виробництво і обслуговування виробничих фондів, до яких належать: сільськогосподарські землі, аграрна техніка. Велика увага приділяється логістиці руху оборотного капіталу: посівного матеріалу у рослинництві, розвитку селекції у сфері тваринництва та птахівництва, виробництву та закупівлі мінеральних добрив тощо. Важливе місце у аграрному виробництві займає рівень розвитку та інноваційного переоснащення наявних об'єктів інфраструктури - елеваторів, сушарок та складських приміщень для зберігання зібраного врожаю. Особливу роль у системі аграрного виробництва відіграє логістика транспортного забезпечення; налагодження логістики руху аграрної продукції «від лану - до столу», тобто з місця вирощування продукції до мережі роздрібної торгівлі та до споживача.

Цикл обороту капіталу у аграрному виробництві переважної більшості країн світу становить один рік. За таких обставин аграрії надають перевагу коротким термінам окупності інвестицій, які вливаються у сферу аграрного виробництва. На рисунку 1 представлено динаміку прямих іноземних інвестицій (ПІІ) до сфрери агарного виробництва в масштабах світового господарства за період 2005 - 2017 рр. Як свідчать наведені дані, «пік» інвестиційної активності ПІІ у світове аграрне виробництво припадав на період 2007 - 2010 рр. (це передкризовий період - до початку світової фрінансово-економічної кризи) та у перші роки післякризового періоду, під час якого відбувалися процеси активного інноваційно-технічного переоснащення виробничих комплексів аграрно-промислового виробництва. Інвестування у технічне оснащення аграрного виробництва ставило за мету здійснити його кардинальну технічну модернізацію на інноваційних засадах із застосуванням IT-технологій, розробок цифрової економіки, забезпечити перехід до «високоточного аграрного виробництва».

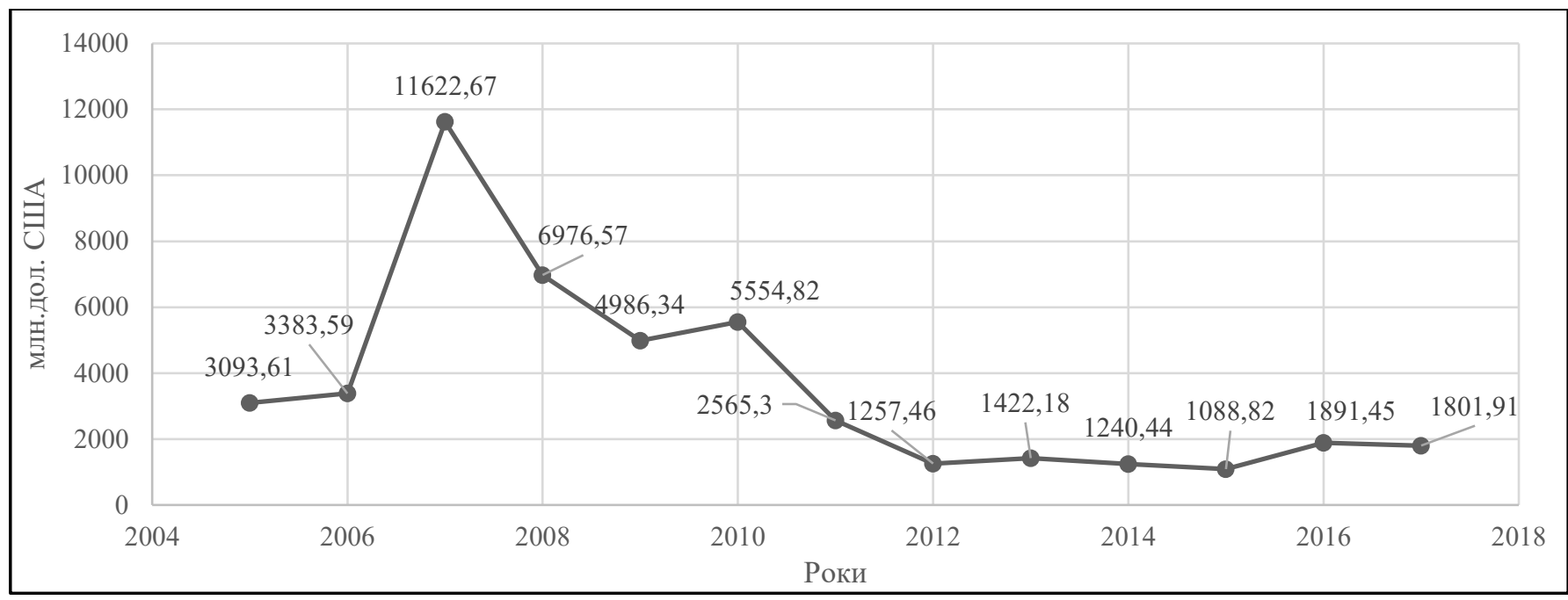

Рисунок 1. Динаміка прямих іноземних інвестицій у сферу розвитку світового аграрного виробництва за період 2005 - 2017 рр. (млн. дол. США). Джерело: World Investment Report 2018 [5]. 
Серед регіонів-лідерів ПІІ у сфреру розвитку аграрного виробництва за період з 2005 по 2017 рр. - країни Азії, Європейський Союз, країни Північної та Південної Америки. Такі інвестиції здійснювалися, в основному, ТНК спільно з ТНБ та стосувалися як інвестування у технічне переоснащення аграрного виробництва, так і інвестицій у придбання земельних ресурсів (купівлю земель сільськогосподарського призначення). 3 даних, наведених у таблиці 1 видно, що серед угод, які уклали іноземні інвестори (насамперед - ТНК) за межами своєї країни, на світових ринках, переважають угоди для придбання земель сільськогосподарського призначення з подальшим виробництвом на придбаних землях продукції рослинництва та вирощування технічних культур - 39 \% від загальної площі придбаних за означений період угод (в основному, це кукурудза, пшениця, соя, рапс та технічні культури). Такі угоди характеризуються великими капіталовкладеннями у інноваційно-технічне оснащення аграрного виробництва, у розвиток механізації та автоматизації з переходом до високоточного, високопродуктивного, стандартизованого та моноструктурного аграрного виробництва 3 мінімальним використанням найманої праці.

Таблиця 1. Спеціалізація угод з придбання земель сільськогосподарського призначення у світі (за період 2000-2017 рр.)

\begin{tabular}{|c|c|c|c|c|}
\hline Ціль інвестування & $\begin{array}{c}\text { Кількість } \\
\text { угод }\end{array}$ & $\begin{array}{c}\text { Площа } \\
\text { угідь, га }\end{array}$ & \begin{tabular}{|c|} 
Питома вага від \\
загальної площі \\
угідь, у відсотках, \%
\end{tabular} & $\begin{array}{c}\text { Середній розмір } \\
\text { с/г угідь у розрахунку } \\
\text { на одну угоду, га }\end{array}$ \\
\hline \multicolumn{5}{|c|}{ Угоди, які здійснюють іноземні інвестори на світових ринках і які ставлять за мету виробництво: } \\
\hline біопалива & 188 & 8071550 & \begin{tabular}{|c|}
16,3 \\
\end{tabular} & 42934 \\
\hline продукції рослинництва & 388 & 19409763 & 39,3 & 50025 \\
\hline продукції тваринництва & 60 & 916550 & 1,9 & 15276 \\
\hline непродовольчих товарів & 113 & 1299438 & 2,6 & 11499 \\
\hline Багатоцільове призначення & 334 & 13199370 & 26,7 & 39519 \\
\hline Угоди невизначеного характеру & 172 & 6552137 & 13,3 & 38094 \\
\hline Усього & 1255 & 49448808 & 100,0 & 39401 \\
\hline \multicolumn{5}{|c|}{ Угоди, які здійснюють інвестори на внутрішньому, національному ринку країни для виробництва: } \\
\hline біопалива & 76 & 758141 & \begin{tabular}{|l|l|}
1,0 & \\
\end{tabular} & 9976 \\
\hline продукції рослинництва & 89 & 1610424 & 2,2 & 18095 \\
\hline продукції тваринництва & 25 & 218848 & 0,3 & 8754 \\
\hline непродовольчих товарів & 36 & 182233 & 0,3 & 5062 \\
\hline Багатоцільове призначення & 123 & 68034258 & 94,0 & 553124 \\
\hline Угоди невизначеного характеру & 66 & 1572285 & 2,2 & 23823 \\
\hline Усього & 415 & 72376189 & 100,0 & 174400 \\
\hline \multicolumn{5}{|c|}{ Загальна кількість угод для виробництва, світ в цілому: } \\
\hline біопалива & 264 & 8829691 & 7,2 & 33446 \\
\hline продукції рослинництва & 477 & 21020187 & 17,3 & 44067 \\
\hline продукції тваринництва & 85 & 1135398 & 0,9 & 13358 \\
\hline непродовольчих товарів & 149 & 1481671 & 1,2 & 9944 \\
\hline Багатоцільове призначення & 457 & 81233628 & 66,7 & 177754 \\
\hline Угоди невизначеного характеру & 238 & 8124422 & 6,7 & 34136 \\
\hline Усього & 1670 & 121824997 & 100,0 & 72949 \\
\hline
\end{tabular}

Джерело: Dynamics overview. LAND MATRIX [6].

Серед угод з ПІІ, які уклали іноземні інвестори на внутрішньому, національному ринку країн походження ТНК (потужних агро-фірм), в основному, переважали угоди для придбання земель сільськогосподарського призначення з подальшим виробництвом на них продукції багатоцільового призначення - понад 94,0 \% від загальної площі придбаних за означений період (2000-2017рр.) земель. Багатоцільове призначення передбачає як вирощування зернових, сировини для подальшої промислової переробки, так і розвиток замкнених та експортоорієнтованих аграрно-виробничих комплексів (аграрних кластерів) 3 птахівництва та тваринництва, а також - комплексне вирощування зернових та масляних культур з подальшою переробкою їх відходів на потреби відновлюваної енергетики у вигляді пелетів, брикетів та інших видів біопалива. Отже, можна зробити висновок (дивись табл. 1), що ПІІ ТНК (агро-фрірм) з придбання земель сільськогосподарського призначення за кордоном (в країнах, що розвиваються), в основному, зорієнтовані на фрормування сировинної бази, а внутрішні ПII агро-фрірм та ТНК у межах національної економіки країн їх базування - на створення конкурентоспроможних агро-комплексів багатоцільового призначення.

Лідерами у сфері інвестування аграрного виробництва у світовій економіці є аграрні ТНК. Зазначимо, що саме аграрні ТНК у XXI ст. стають драйверами переходу до інновацій та «високих технологій». Серед відомих у світі прикладів інновацій, застосування IT-рішень у сфері аграрного виробництва є: інноваційні та дистанційні системи управління підприємством (ERP) у аграрній сорері; IT-облікові системи; IT-системи електронного документообігу, інновації у сфері супутникового зв'язку і навігації; інновації у сфрері 
забезпечення безпеки і контролю за використанням автотранспорту в аграрному виробництві, у системі управління персоналом, активами і бізнес-процесами, залучення системи CRM та бізнес-аналітики в процесі розвитку аграрного виробництва. ERP-системи інтегрують у собі різноманітні варіанти застосування IT-рішень у сорері розвитку аграрного виробництва.

Серед найважливіших стратегічних пріоритетів технічного переоснащення аграрного виробництва перехід до високоточного землеробства. Стратегія переходу до «високоточного землеробства» полягає у впровадженні практики максимально-ефективного використання кожного гектара земель, що обробляються; запровадження ІТ-контролю за сходженням посівного матеріалу (озимих, ярових) та за раціональним та рівномірним внесення добрив; IT-контроль за ефективним використанням паливно-мастильних матеріалів (ПММ) та засобів захисту рослин (33Р). Стратегія переходу до «високоточного землеробства» ставить за мету скорочення витрат аграрного виробництва та підвищення врожайності. «Високоточне землеробство» активно розвивається у Північній і Південній Америці, Азіатсько-Тихоокеанському регіоні та в країнах Європейського Союзу. Такі країни як Бразилія, Аргентина, Польща, Угорщина, КНР - демонструють стрімке зростання обсягів аграрного виробництва, в основному, за рахунок його концентрації та централізації, нарощування експортного потенціалу великих аграрних підприємств, агрохолдінгів, аграрних ТНК. Натомість, пріоритетом високоточного аграрного виробництва стає розвиток моноструктурного рослинництва, спеціалізація на вирощуванні технічних культур, що спрощує застосування техніки та мінімізує витрати коштів на найм робочої сили.

У ТОП-10 ТНК, що станом на 2019 р. домінували на світовому аграрному ринку входять шість американських компаній, дві компанії з Німеччини, ТНК з Швейцарії та Нідерландів (дивись табл. 2). Всі ТНК - лідери світового аграрного виробництва у своїй діяльності активно застосовують як ГМО, так і розвивають екологічне аграрне виробництво (орієнтуючись на конкретні сегменти споживачів); широко застосовують гербіциди, фунгіциди, інсектіциди, систему захисту посівного матеріалу (насіння), регулятори росту рослин, різноманітні агрохимікати. Серед інноваційних досліджень ТНК - і споріднені з агро-бізнесом сфери, у т.ч. медичні дослідження. Так, BASF ще у 2016 р. проводила дослідження інноваційного напряму «нутрігеномікі», що вивчає вплив харчування та поживних речовин на гени людини. ТНК масово розвивають рослинництво, у т.ч. вирощування технічних рослин та харчові зернові культури (зерно, соя, рапс, кукурудза та ін.). Аграрні транснаціональні компанії - Syngenta AG, Monsanto Company, BASF, Bayer AG, DowDuPont та інші THK - на світовому ринку тісно співпрацюють, утворюючи олігополістичний ринок та формуючи картельні ціни, що дозволяє не тільки утримувати у світі досить високі ціни на аграрну продукцію, але й щорічно підвищувати світові ціни на готові харчові продукти масового споживання, отримуючи за рахунок цього надприбутки та монопольну ренту.

Таблиця 2. ТОП-10 ТНК у сфері світового аграрного виробництва, 2019 р.

\begin{tabular}{|c|l|l|c|}
\hline Місце у рейтингу & \multicolumn{1}{|c|}{ Бренд ТНК } & Країна походження & $\begin{array}{c}\text { Річний дохід ТНК, } \\
\text { млрд. дол. США }\end{array}$ \\
\hline 1 & Cargill & США & 107,20 \\
\hline 2 & Archer Daniels Midland Company & США & 62,35 \\
\hline 3 & Deere \& Company & США & 18,49 \\
\hline 4 & DowDuPont & США & 15,69 \\
\hline 5 & Nutrien (Formerly Agrium Inc. and PotashCorp) & США & 13,67 \\
\hline 6 & Monsanto Company & США & 13,50 \\
\hline 7 & Syngenta AG & Швейцарія & 12,79 \\
\hline 8 & Bayer AG & Німеччина & 11,66 \\
\hline 9 & CNH Industrial NV & Нідерланди & 10,12 \\
\hline 10 & BASF & Німеччина & 6,55 \\
\hline
\end{tabular}

Джерело: Top Ten Agribusiness Companies in the World [7].

Перехід аграрних ТНК до масового застосування високоточного землеробства створює прецендент для копіювання такого досвіду іншими аграрними компаніями, фрермерскими господарствами у країнах, для яких аграрний сектор відіграє важливу роль у фрормуванні національного ВВП. Для промислового, масового впровадження технологій високоточного землеробства необхідні сучасні інноваційні та IT-технології: сенсори, інформаційні системи обробки та аналізу даних, в яких все частіше застосовуються технології інтелектуального аналізу даних (data mining), засновані на автономному машинному самоналаштуванні та самонавчанні.

Переваги високоточного аграрного виробництва стають наочними, що обумовлює масовий перехід аграрних фірм, аграрних ТНК та фермерства різних країн світу до застосування IT та інших інноваційних технологій. Так, у сфері «високоточного землеробства» активно розвиваються наступні напрямки:

- космічні та авіаційні технології, що дозволяють в режимі online отримувати реальну та актуальну інформацію (у т.ч. фрото-знімки високої якості), надають інформацію про всі процеси, що відбуваються на полях, в лісах, контролюють стан водних ресурсів, визначають ризики пожеж та паводків, надають оцінки їх мінімізації;

- безпілотні технології, безпілотні літальні апарати (БПЛА) відіграють важливу роль у процесі забезпечення контролю за врожайністю, оцінюють рівень та якість сходження рослин на полях, потребу у здійсненні додаткових посівів тощо; 
- застосування мультиспектральних, гіперспектральних, мікрохвильових сенсорів (у т.ч. розміщених на основі БПЛА);

- масовий перехід до використання апаратури онлайн-аналізу грунту, що призначена для визначення стану передпосівної готовності та рівня обробки грунту, а також і для інших агротехнологічних операцій;

- поширення інноваційної технології «агроскаутинг» (для якої застосовують і мобільні додатки), що забезпечує оперативний процес збору інформації про стан, якість та відповідність рослин певним параметрам та стандартам їх розвитку безпосередньо на полях;

- запровадження автоматизованої системи моніторингу та контролю машинно-тракторного парку, заснованої на використанні систем супутникової навігації та бортової телеметрії;

- впровадження ІТ-системи обліку витратних матеріалів; впровадження онлайн-датчиків обліку паливно-мастильних матеріалів, насіння, добрив, засобів захисту рослин та іншої інформації, яка передається диспетчеру агро-фрірми по каналам зв'язку в режимі online;

- поширення систем інтелектуального управління процесами висіву, внесення добрив та засобів захисту рослин, масове інноваціне «розумне» технічне оснащення агрегатів для цих цілей (сівалок, плугів, розрідження, боронування та ін.).

- прогнозування і моделювання процесів та обсягів врожайності на основі інтелектуальних систем підтримки прийняття рішень, інтегруючих дані, отриманих з різних інформаційних джерел збору даних [8; 9].

Слід зазначити, що в найбідніших країнах світу, що розвиваються, аграрний сектор відіграє важливу роль. Так, питома вага сільського господарства у секторальній структурі ВВП станом на 2018 р. (у відсотках до ВВП) становила: Ліберія - 76,9 \%; Сомалі - $65 \%$; Гвінея-Бісау - 62 \%; Конго - 55 \%; Центральна Африканська Республіка - 55 \%; Сьера- Леоне - 49 \%; Малі - 45 \%; Ефіопія - 44,9 \%; Камерун - 43,6 \%; Руанда - 43,2 \%; Соломонові острови - 42 \%; М'янма - 40,9\%; Того - $40 \%$; Лаос - 39,2 \% та ін. [10; 11]. Водночас, аграрне виробництво у цих країнах ведеться на старих, не інноваційних засадах та, в основному, спеціалізується на виробництві продукції рослинництва, зернових та технічних культур як сільськогосподарської сировини та для власного споживання домогосподарств. Такі країни, як правило, експортують аграрну сировину і для них дуже високий ризик голоду на внутрішньому ринку. Коштів на імпорт продуктів харчування у бідних країн, як правило, немає, і уряди цих країн часто звертаються за допомогою до міжнародних організацій (у т.ч. до ООН) для отримання міжнародної гуманітарної допомоги. У світі серед країн-лідерів експорту харчових продуктів (станом на 2018 р.) перебувають індустріальні, високорозвинені країни та країни, які масово переходять до високоточного аграрного виробництва: Європейський Союз - 41,1\%; США - $11 \%$; Бразилія - 5,7 \%; Китай 4,2 \%; Канада - 3,4 \%; Аргентина - 2,8 \%; Австралія - 2,5 \%; Індонезія - 2,4 \%; Мексика - 2,3 \%; Індія - 2,2 \% від загального обсягу експорту сільськогосподарської продукції у світовій економіці [10; 12$].$

Найбільш активно високоточне аграрне виробництво розвивається у країнах Західної та Східної Європи. Станом на 2018 р. лідерами у сфері розвитку високоточного аграрного виробництва у Східній Європі стали такі країни як: Румунія -6,4%; Болгарія - 6,7 \%; Боснія і Герцеговина - 8,45 \%; Республіка Білорусь 9,2 \%; Сербія - 9,66 \%; Чорногорія - 10,1\%; Македонія - 10,2 \%; Україна - 12,1\%; Молдова - 13,8 \% та Албанія - 21,83 \% яких, відповідно, становить частка сільськогосподарського виробництва у структурі ВВП вищеназваних країн [10; 11]. В цілому - спеціалізація країн виключно на розвитку аграрного виробництва не дає вагомих результатів у забезпеченні економічного зростання. Тільки поєднання розвинутого, інноваційного та технологічно оснащеного агропромислового комплексу з розвитком конкурентного індустріального промислового виробництва, що використовує напрацювання «Індустрії 4.0», NBIC-технології та інші інноваційні здобутки, забезпечує для країни гарні конкурентні позиції на світовому ринку та лідируючі позиції у світовому господарстві.

Висновки. Дослідження стратегій виробництва аграрної продукції у світовій економіці дає підстави зробити висновки про те, що «економічними центрами» масового аграрного виробництва в усіх країнах світу є: фрермерські господарства та агрохолдінги (агрофрірми), аграрні ТНК. Фермерські господарства спеціалізуються, в основному, на виробництві дрібнотоварної аграрної трудомісткої продукції - овочівництво, садівництво, бджолярство та ін. Великі агро-фрірми та аграрні ТНК обирають стратегію спеціалізації на масовому індустріальному розвитку тваринництва та птахівництва, на виробництві моноструктурної аграрної продукції рослинництва: зерно, кукурудза, соя, технічні культури. У світі саме експортний аграрний потенціал ТНК та великих національних агро-фрірм задовольняє глобальний попит на аграрну сировину та продукти харчування.

Наявність значних обсягів земельного банку у ТНК у розвинутих країн світу та в країнах, що розвиваються, мають різне призначення. У розвинених країнах світу ТНК використовують стратегії багатоцільового використання сільськогосподарських земель, у т.ч. для виробництва сільськогосподарської продукції з високим вмістом доданої вартості; для глибинної переробки продукції тваринництва, рослинництва; для розвитку відновлюваної енергетики та біоенергетики. Такі угоди характеризуються великими капіталовкладеннями у інноваційно-технічне оснащення аграрного виробництва, у розвиток механізації та автоматизації з переходом до високоточного, високопродуктивного, стандартизованого та моноструктурного аграрного виробництва з мінімальним використанням найманої праці. Натомість, для ТНК розвинених країн світу придбання сільськогосподарських земель в країнах, що розвиваються (у т.ч. за допомогою ПІІ), дозволяє втілити стратегію долучення придбаних земель, в основному, для розвитку рослинництва як сировинної бази для її подальшої переробки в країнах походження ТНК. 
У розвинених країнах світу та у країнах-лідерах аграрного експорту загальним трендом стає застосування інноваційних технологій, перехід до високоточного аграрного виробництва з використанням IT-технологій, авіаційних та космічних технологій, дронів, використання ГМО для збільшення продуктивності, максимізації врожайності аграрних господарств та мінімізації впливу ризиків дефріциту води та високих температур у літній період на врожайність, внаслідок зміни клімату. Перехід до високоточного аграрного виробництва вже відбувся у США, в країнах ЄС, активно відбувається у КНР, Аргентині, Бразилії, Індії та інших країнах світу.

Усвідомлення важливості стратегії переходу до високоточного аграрного виробництва надзвичайно важливо для України, яка прагне здобути лідерство у експорті аграрної продукції на світовому ринку. Адже без адаптації національного агробізнесу до стандартів високоточного аграрного виробництва, без зниження собівартості виробництва, підвищення його продуктивності та якості - Україна не зможе конкурувати на світовому ринку аграрної продукції. Наступним кроком для України має стати налагодження переробки аграрної сировини та виробництво готових продуктів харчування з високим вмістом доданої вартості у сфрері національного промислового виробництва, у т.ч. на рівні малого (фермерство) та середнього бізнесу, і звичайно - на рівні великих національних агрохолдингів.

Перспективи подальших розвідок у цьому напрямку. У XXI ст. стратегічні пріоритети розвитку конкурентоспроможного сільськогосподарського виробництва напряму будуть пов'язані із розвитком високоточного аграрного виробництва, що засновано на використанні ІТ-технології, здобутків цифрової економіки та «Індустрії 4.0». Натомість, масовий перехід до високих, інноваційних технологій не тільки підвищує продуктивність праці у аграрному секторі, але й породжує багато соціально-економічних проблем. Серед найбільш гострих - масове безробіття та зменшення потреби у кількості населення, яке проживає у сільській місцевості, у селах. Процеси масової міграції населення з сільських територій до міст - породжують нові системні проблеми, пов'язані з урбанізацією, зростаючим попитом на продукти харчування міського населення, санітарними, психологічними та поведінковими економічними проблемами розвитку людства та світової економіки. Ці питання потребують подальших системних наукових досліджень.

\section{Список використаних джерел}

1. Макаренко П. М., Пілявський В. І. Інноваційно-інвестиційне забезпечення потенціалу стійкого розвитку аграрних підприємств. Економічний вісник університету. Збірник наукових праць учених та аспірантів. Вип. 41. 2019. C. 29-35. https://doi.org/10.31470/2306-546X-2019-41. URL: https://economic-bulletin.com

2. Шульга О. А. Діалектика взаємозв'язку розвитку інституціональних суспільних фрорм функціонування економічних систем та відносин власності в аграрному секторі. Економічний вісник університету. Збірник наукових праць учених та аспірантів. Вип. 41. $2019 . \quad$ C. $35-46$. https://doi.org/10.31470/2306-546X-2019-41. URL: https://economic-bulletin.com

3. Smaller C., and W. Speller, with H. Mirza, N. Bernasconi-Osterwalder, and G. Dixie. 2015. Investment Contracts for Agriculture: Maximizing Gains and Minimizing Risks. Washington, D. C.: World Bank Group; New York: United Nations; and Winnipeg: International Institute for Sustainable Development (IISD). URL: http://documents. worldbank.org/curated/en/143361467997246051/pdf/94895-NWP-PUBLIC-Box391483B-AgriInvestment-Contracts-web-06-11-2015-V2.pdf

4. Keating B., Herrero M., Carberry P. Food wedges: Framing the global food demand and supply challenge towards 2050. Global Food Security. 2014. №3. C. 125-132.

5. World Investment Report 2018. Investment and New Industrial Policies. URL: https://unctad.org/en/ PublicationsLibrary/wir2018_en.pdf

6. Dynamics overview. LAND MATRIX. URL: http://www.landmatrix.org/en/get-the-idea/dynamics-overview/.

7. Top Ten Agribusiness Companies in the World. URL: https://www.tharawat-magazine.com/facts/top-tenagribusiness-companies/\#gs.snOkOg

8. Technological Innovation for Agricultural Statistics. - International Rice Research Institute (IRRI). 2013. Rice Almanac. Los Banos. URL: http://books.irri.org/9789712203008_content.pdf.

9. Klasen S. and Reimers M. The Pros and Cons of Drones in Agriculture. Drone Guru. 2016. URL: http://www.droneguru.net/the-pros-and-cons-of-drones-inagriculture

10. Офріційний сайт Продовольчої та сільськогосподарської організації OOH. FAO. URL: http://www.fao.org

11. World Trade Statistical Review 2019. Highlights of world trade. URL: https://www.wto.org/english/res_e/ statis_e/wts2019_e/wts2019chapter02_e.pdf

12. Challenges and opportunities of foreign investment in developing country agriculture for sustainable development. URL: http://www.fao.org/3/a-i4074e.pdf

\section{References}

1. Makarenko, P. M. \& Pilyavskij, V. I. (2019). Innovacijno-investicijne zabezpechennya potencialu stijkogo rozvitku agrarnih pidpriyemstv [Innovative and investment support for the potential of agricultural enterprises sustainable development]. Ekonomichnij visnik universitetu - University Economic Bulletin, $41.29-35$. https://doi.org/10.31470/2306-546X-2019-41, URL: https://economic-bulletin.com

2. Shulga, O. A. (2019). Dialektika vzayemozv'yazku rozvitku institucionalnih suspilnih form funkcionuvannya ekonomichnih sistem ta vidnosin vlasnosti $v$ agrarnomu sektori [Dialectics of interaction of the development of 
institutional social forms of economic systems and property relationships functioning in the agricultural sector. University Economic Bulletin]. Ekonomichnij visnik universitetu - University Economic Bulletin, $41.35-46$. https://doi.org/10.31470/2306-546X-2019-41. URL: https://economic-bulletin.com

3. Smaller C., and W. Speller, with H. Mirza, N. Bernasconi-Osterwalder, and G. Dixie. (2015). Investment Contracts for Agriculture: Maximizing Gains and Minimizing Risks. Washington, D.C.: World Bank Group; New York: United Nations; and Winnipeg: International Institute for Sustainable Development (IISD). URL: http://documents.worldbank.org/curated/en/143361467997246051/pdf/94895-NWP-PUBLIC-Box391483B-Agri-

Investment-Contracts-web-06-11-2015-V2.pdf

4. Keating, B., Herrero, M. \& Carberry, P. (2014). Food wedges: Framing the global food demand and supply challenge towards 2050. Global Food Security, 3. 125-132.

5. World Investment Report 2018. Investment and New Industrial Policies. URL: https://unctad.org/en/ PublicationsLibrary/wir2018_en.pdf

6. Dynamics overview. LAND MATRIX. URL: http://www.landmatrix.org/en/get-the-idea/dynamics-overview/.

7. Top Ten Agribusiness Companies in the World. URL: https://www.tharawat-magazine.com/facts/top-tenagribusiness-companies/\#gs.snOkOg

8. Technological Innovation for Agricultural Statistics. - International Rice Research Institute (IRRI). 2013. Rice Almanac. Los Banos. URL: http://books.irri.org/9789712203008_content.pdf.

9. Klasen S. and Reimers M. (2016). The Pros and Cons of Drones in Agriculture. Drone Guru. URL: http://www.droneguru.net/the-pros-and-cons-of-drones-inagriculture

10. Oficijnij sajt Prodovolchoyi ta silskogospodarskoyi organizaciyi OON. FAO. URL: http://www.fao.org

11. World Trade Statistical Review 2019. Highlights of world trade. URL: https://www.wto.org/english/ res_e/statis_e/wts2019_e/wts2019chapter02_e.pdf

12. $\bar{C}$ hallenges and opportunities of foreign investment in developing country agriculture for sustainable development. URL: http://www.fao.org/3/a-i4074e.pdf

\section{ДАНІ ПРО АВТОРА}

Біла Світлана Олексіївна, доктор наук з державного управління, професор, професор кафедри міжнародних економічних відносин і бізнесу, заслужений економіст України.

Факультет міжнародних відносин (ФМІ). Національний авіаційний університет (НАУ), просп. Любомира Гузара 1 (просп. Космонавта Комарова 1), м. Київ, 03680, Україна.

e-mail: svbila_2012@ukr.net

orcid.org/0000-0003-3909-5054

Researcher ID: F-7237-2018

\section{ДАННЫЕ ОБ АВТОРЕ}

Белая Светлана Алексеевна, доктор наук государственного управления, профессор, профессор кафедры международных экономических отношений и бизнеса, заслуженный экономист Украины.

Факультет международных отношений (ФМО). Национальный авиационный университет (НАУ), просп. Любомира Гузара 1 (просп. Космонавта Комарова 1), г. Киев, 03680, Украина.

e-mail: svbila_2012@ukr.net

\section{DATA ABOUT THE AUTHOR}

Bila Svitlana, Doctor of Public Administration, Professor, Professor of International Economic Relations and Business Department, Honored economist of Ukraine.

Faculty of International Relations (FIR). National Aviation University (NAU), prosp. Liubomir Guzar 1 (prosp. Kosmonavta Komarova 1), Kyiv, 03680, Ukraine.

e-mail: svbila_2012@ukr.net

\section{ІНВЕСТИЦІЙНЕ ЗАБЕЗПЕЧЕННЯ СТВОРЕННЯ РОБОЧИХ МІСЦЬ В АГРАРНІЙ СФЕРІ}

Ланченко Є. 0.

Актуальність. В економічному механізмі регулювання ринку праці в аграрній сфрері велике значення має прогнозування й збалансування пропозиції і попиту на робочу силу залежно від обсягів виробництва сільськогосподарської продукції та відповідне формування реальних інвестицій у створення робочих місць у галузі. Тому актуальним є напрям дослідження інвестиційних процесів і зайнятості населення в аграрній сфері.

Постановка проблеми. Інвестиційні процеси в сільському господарстві України мають забезпечувати відтворювальні процеси в галузі, поліпшення структури засобів виробництва й залучення 